\title{
Cytological Observations on some W. Himalayan Monocots V. Araceae
}

\author{
P. N. Mehra and S. K. Sachdeva \\ Department of Botany, Panjab University, Chandigarh, India
}

Received May 16, 1974

According to Airy Shaw (1966) the family comprises 115 genera and nearly 2,000 species distributed chiefly in the tropical countries of the world. In the Indian sub-continent the family is represented by 32 genera and 227 species (Hooker 1894).

The present investigation covers nine species belonging to three genera Arisaema, Sauromatum and Typhonium. All of these fall under the tribe Areae of Hutchinson (1959). Cytological investigations have appeared in the past by Ito (1942), Bowden (1940, 1945), Malik (1961), Sharma and Mukhopadhyay (1965), Larsen (1969), Hotta (1971) and Marchant (1972) on Arisaema, by TschermakWoess (1954), Earl (1955) and Marchant (1972) on Sauromatum and by Ito (1942), Simmonds (1954), Briggs (in Evans 1962), Sharma and Mukhopadhyay (1965), Larsen (1969) and Marchant (1972) on Typhonium. Apart from the work of Malik (1961) no other reports on members of this family from this region are available. Considering the paucity of information on W. Himalayan taxa, the present study was undertaken.

\section{Material and methods}

The materials were all collected from the wild. The methods followed were the same as described earlier (Mehra and Sachdeva, in this journal).

\section{Observations}

Table 1 lists the species, their chromosome numbers and the locality from which they were collected.

Arisaema Mart.

The genus constitutes 150 species (Airy Shaw 1966) distributed in temperate and tropical Asia and North America. Eight species occur in the W. Himalayas (Hooker 1894). Seven of these have been studied.

A. concinnum Schott. The species grows commonly in the Kumaon hills at an altitude of $1,800-2,400 \mathrm{~m}$. The chromosome number was determined from roottip mitoses which revealed $2 n=28$ (Fig. 1). The karyotype consisted of six pairs of median, seven pairs of submedian and one pair of subterminal chromosomes. None of the chromosomes showed any secondary constriction. The chromosome size ranged from $6 \mu$ to $3 \mu$. The present report is of a new cytotype. Earlier Bowden (1940) reported $2 \mathrm{n}=56$ in this species. 
Table 1 .

\begin{tabular}{|c|c|c|c|c|c|c|}
\hline Taxa & $\begin{array}{l}\text { Specific } \\
\text { locality and } \\
\text { altitude }\end{array}$ & $\begin{array}{l}\text { Chror } \\
\text { nur } \\
n\end{array}$ & $\begin{array}{l}\text { osome } \\
\text { ber } \\
2 n\end{array}$ & $\begin{array}{l}\text { Fig. } \\
\text { no. }\end{array}$ & & Previous reports \\
\hline $\begin{array}{l}\text { + Arisaema concinnum } \\
\text { Schott. }\end{array}$ & $\begin{array}{l}\text { Khati, } \\
\text { Almora, } \\
1,700 \mathrm{~m}\end{array}$ & & 28 & 1 & $2 n=56$ & : Bowden 1940 \\
\hline$+A$. curvatum Kunth. & $\begin{array}{l}\text { Jeolikote, } \\
\text { Nainital, } \\
1,400 \mathrm{~m}\end{array}$ & & 28 & 2 & $2 n=26$ & Malik 1961 \\
\hline A. erubescens Schott. & $\begin{array}{l}\text { Nainital, } \\
2,100 \mathrm{~m}\end{array}$ & & 28 & 3 & $2 n=28$ & $\begin{array}{l}\text { Larsen 1969, Sharma } \\
\text { and Sarkar 1967-68 }\end{array}$ \\
\hline A. intermedium B1. & $\begin{array}{l}\text { Khati, } \\
\text { Almora, } \\
1,700 \mathrm{~m}\end{array}$ & & 28 & 4 & $2 n=28:$ & Malik 1961 \\
\hline+ A. jacquemontii B1. & $\begin{array}{l}\text { Baggi, } \\
\text { Simla, } \\
2,800 \mathrm{~m}\end{array}$ & & 52 & 5 & $2 n=28:$ & Malik 1961 \\
\hline A. tortuosum Schott. & $\begin{array}{l}\text { Baggi, } \\
\text { Simla, } \\
2,800 \mathrm{~m}\end{array}$ & & 28 & 6 & $\begin{array}{l}2 n=26: \\
2 n=24: \\
2 n=28\end{array}$ & $\begin{array}{l}\text { Malik } 1961 \text {; } \\
\text { Sharma and Mukho- } \\
\text { padhyay } 1965 ; \\
\text { Hotta } 1971\end{array}$ \\
\hline A. wallichianum Hook. & $\begin{array}{l}\text { Retreat, } \\
\text { Simla, } \\
2,400 \mathrm{~m}\end{array}$ & 14 & & 7 & $2 n=28$ & Malik 1961 \\
\hline $\begin{array}{l}\text { Sauromatum venosum } \\
\text { (Ait.) Kunth. }\end{array}$ & $\begin{array}{l}\text { Annadale, } \\
\text { Simla, } \\
1,800 \mathrm{~m}\end{array}$ & & 26 & 8 & $\begin{array}{l}2 n=32: \\
2 n=26\end{array}$ & $\begin{array}{l}\text { Delay } 1950 \text {; } \\
\text { Tschermak-Woess } 1954 \text {, } \\
\text { Earl } 1955\end{array}$ \\
\hline $\begin{array}{l}\text { Typhonium diversifolium } \\
\text { Wall. }\end{array}$ & $\begin{array}{l}\text { Dhakri, } \\
\text { Almora, } \\
2,700 \mathrm{~m}\end{array}$ & & 52 & 9 & $2 n=52$ & Jones 1957 \\
\hline
\end{tabular}

+ New chromosome number report (New cytotype).

A. curvatum Kunth. It is widespread in the Kumaon hills between 1,500$2,100 \mathrm{~m}$. Somatic chromosome number as determined from root-tip mitoses was found to be $2 n=28$ (Fig. 2). The chromosome size was exceptionally small. The present count differs from that of Malik (1961) who recorded $2 \mathrm{n}=26$.

A. erubescens Schott. The species occurs in the Kumaon hills between 1,500 $2,100 \mathrm{~m}$. Root-tip mitoses revealed $2 \mathrm{n}=28$ (Fig. 3). The chromosomes were of small size. The present finding confirms the reports by Larsen (1969) and Sharma and Sarkar (1967-68).

$A$. intermedium $\mathrm{Bl}$. This species is very common in the Simla and Kumaon hills between 1,950-2,400 m. Root-tip mitoses showed $2 \mathrm{n}=28$ (Fig. 4). The karyotype consisted of seven pairs of median and seven pairs of submedian chromosomes. No secondary constriction was observed. The chromosome size ranged from $4.5 \mu$ to $2 \mu$. The present report is in conformity with that of Malik (1961).

Figs. 1-5. 1, Arisaema concinnum, $2 \mathrm{n}=28$ in root-tip mitosis. 2, A. curvatum, $2 \mathrm{n}=28$ in root-tip mitosis. 3, A. erubescens, $2 \mathrm{n}=28$ in root-tip cell. $4, A$, intermedium, $2 \mathrm{n}=28$ in root-tip cell. 5 , A. jacquemontii, $2 \mathrm{n}=52$ in root-tip mitosis. All $\times 2500$. 


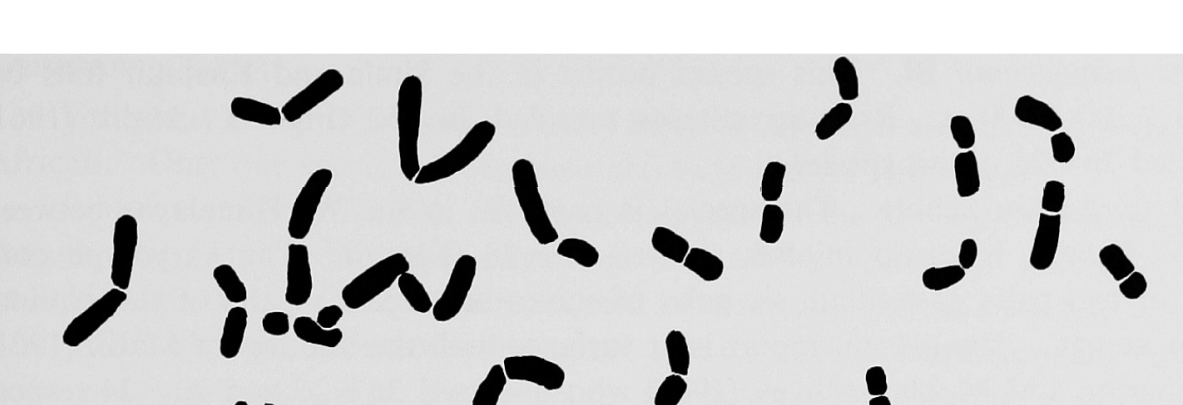

$$
\begin{aligned}
& \text { 桜: }
\end{aligned}
$$


A. jacquemontii $\mathrm{Bl}$. This species occurs in the Simla and Kashmir hills between 2,100-3,600 m. Root-tip mitoses revealed $2 n=52$ (Fig. 5). Malik (1961) recorded $2 \mathrm{n}=28$ in this species.

A. tortuosum Schott. The species is common in the W. Himalayas between $1,950-2,400 \mathrm{~m}$. Root-tip mitoses showed $2 \mathrm{n}=28$ (Fig. 6). The karyotype consisted of two pairs of median, six pairs of submedian and six pairs of subterminal chromosomes. The present report is at variance with the findings of Malik (1961) and Sharma and Mukhopadhyay (1965) who observed $2 n=26$ and $2 n=24$ respectively but confirms the number reported by Hotta (1971).

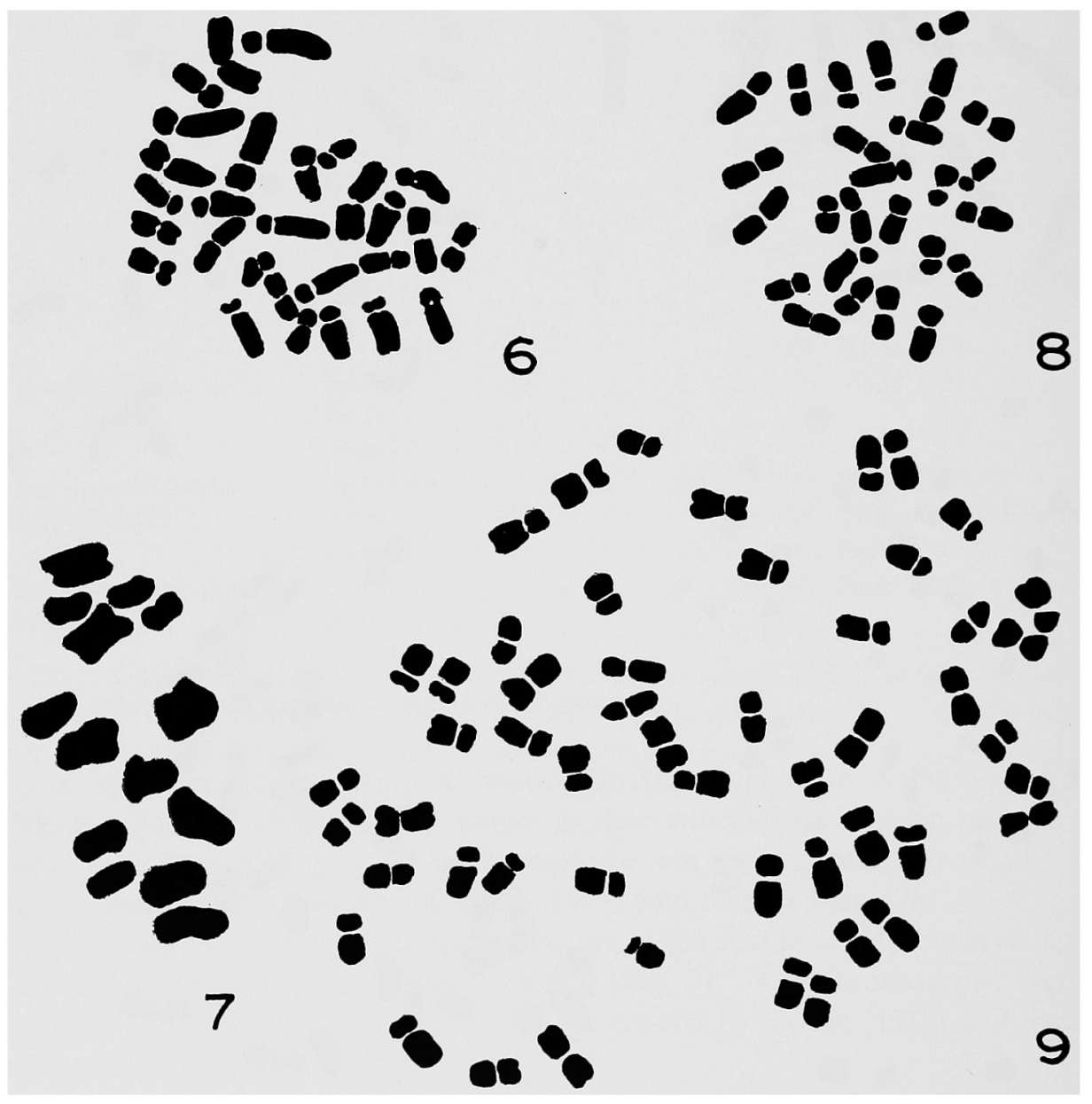

Figs. 6-9. 6, Arisaema tortuosum, $2 \mathrm{n}=28$ in root-tip cell. 7, A. wallichianum, $\mathrm{n}=14$ at $\mathbf{M}_{\mathbf{I}}$. 8 , Sauromatum venosum, $2 \mathrm{n}=26$ in root-tip mitosis. 9, Typhonium diversifolium, $2 \mathrm{n}=52$ in root-tip mitosis. All $\times 2500$.

A. wallichianum Hook. This species is widespread in the Simla, Kumaon and Kashmir hills between $1,800-2,400 \mathrm{~m}$. The chromosome number could only be determined from PMCs which revealed $n=14$ (Fig. 7). Meiosis was normal. The present count is in line with the report of Malik (1961). 
Sauromatum Schott.

The genus constitutes 6 species (Airy Shaw 1966) which are tropical Asiatic and African. Only one species, $S$. venosum occurs in the W. Himalayas.

$S$. venosum (Ait.) Kunth. The species grows in the Simla and Kumaon hills, though not very commonly, ascending to $1,650 \mathrm{~m}$. Root-tip mitoses showed $2 n=26$ (Fig. 8). The karyotype consisted of three pairs of median, eight pairs of submedian and two pairs of subterminal chromosomes. No secondary constrictions were observed. The chromosomes are small. The present report confirms the findings of Tschermak-Woess (1954), Earl (1955) and Marchant (1972) but differs from the finding of $2 n=32$ by Delay (1950).

\section{Typhonium Schott.}

The genus comprises 30 species distributed in S.E. Asia in the Indo-Malayan region (Airy Shaw 1966).

T. diversifolium Wall. This species is widespread in the Kumaon and Simla hills between $1,800-2,850 \mathrm{~m}$. The somatic chromosome number as determined from root-tip mitoses was $2 \mathrm{n}=52$ (Fig. 9). The karyotype consisted of four pairs of median, twenty pairs of submedian and two pairs of subterminal chromosomes. The present report conforms to the number reported by Jones (1957).

\section{Discussion}

Arisaema: Of the seven species studied, six exhibit constancy in the somatic number $(2 \mathrm{n}=28)$ and are based on $\mathrm{x}=14$. A. jacquemontii with $2 \mathrm{n}=52$ seems to be tetraploid based on $\mathrm{x}=13$. Karyotype analysis of $A$. concinnum, $A$. intermedium and $A$. tortuosum shows that though the karyotype is symmetrical in all the three species, it is of primitive type in $A$. intermedium and $A$. concinnum and of somewhat advanced type in $A$. tortuosum. A perusal of the literature reveals that majority of the species studied so far correspond to the series $\mathrm{x}=14$ and are diploid. However, polyploid numbers have been reported in a few species i.e. $2 \mathrm{n}=56$ in $A$. concinnum (Bowden 1940), A. triphyllum (Huttleston 1949), A. kiushianum, A. ovale, A. robustum and $A$. sadoense (Ito 1942) and $2 \mathrm{n}=\mathrm{c} .140$ in $A$. heterophyllum (Ito 1942). Intraspecific polyploidy was recorded by Huttleston (1949) in $A$. triphyllum. The present authors observed $2 \mathrm{n}=28$ in $A$. concinnum, whereas $2 \mathrm{n}=56$ was reported by Bowden (1940) in this species, establishing another example of intraspecific polyploidy. Aneuploid series have been recorded in A. serratum $(2 \mathrm{n}=26$, Nakajima 1933, $2 \mathrm{n}=28$, Ito 1942) and in $A$. limbatum by Ito (1942) who observed cytotypes with $2 \mathrm{n}=28$ and 32 . Present investigations reveal that aneuploidy also occurs in A. curvatum $(2 \mathrm{n}=26$, Malik $1961,2 \mathrm{n}=28$, present report) and in A. tortuosum $(2 \mathrm{n}=26$, Malik 1961, $2 \mathrm{n}=24$, Sharma and Mukhopadhyay $1965,2 \mathrm{n}=28$, Hotta 1971 and present report). It is, thus, evident that intra and interspecific polyploidy along with aneuploidy have played an important role in the evolution of taxa within this genus. Larsen (1969) and Marchant (1972) regarded $x=7$ as the primary base number of this genus. The former author considered 14 to be a derived number. He suggested that $x=6$ was probably derived from 7 and $x=13$ may have arisen 
through amphidiploidy.

Sauromatum: Somatic chromosome number $2 n=26$ for $S$. venosum conforms to the findings of Tschermak-Woess (1954), Earl (1955) and Marchant (1972) but differs from the report of $2 n=32$ by Delay (1950). In view of the present finding, $x=13$ for the genus seems to be more appropriate and not $x=16$ as suggested by Darlington and Wylie (1955).

Typhonium: $T$. diversifolium with $2 \mathrm{n}=52$ is a tetraploid based on $\mathrm{x}=13$. Quite high numbers have been recorded by Briggs (in Evans 1962) in T. brownii $(2 \mathrm{n}=$ c. 160$)$ and T. eliosurum $(2 \mathrm{n}=\mathrm{c} .118,130,152,168) . \quad$ Mitra and Datta (1967) have recorded $n=9,2 n=18$ in T. trilobatum. According to Larsen (1969) the base number $x=13$ is secondary, having arisen from 7 or 6 through amphidiploidy.

\section{Summary}

The cytology of nine W. Himalayan species belonging to three genera Arisaema, Sauromatum and Typhonium has been studied. There is considerable variation in chromosome size in the genus Arisaema. Diploid taxon of A. concinnum $(2 \mathrm{n}=28)$ has been found to occur in the Kumaon hills. Bowden had earlier reported this species to be tetraploid with $2 n=56$. A. curvatum was found to possess $2 n=28$. Malik had earlier observed $2 n=26$ in this species. Previously only the diploid form of A. jacquemontii was known to occur (Malik 1961). Present investigations have revealed the existence of tetraploids based on $\mathrm{x}=13$ in the Simla hills. Sauromatum venosum has $2 \mathrm{n}=26$ and possesses a symmetrical karyotype. The base number $x=13$ is suggested for the genus.

\section{Acknowledgements}

We gratefully acknowledge the financial assistance from U.S. Department of Agriculture under PL 480 Project (Grant No. FG-In-281) to the senior author. Our sincerest thanks are due to the Head of the Division of Botany, F.R.I. Dehradun, for the help in the identification of voucher specimens.

\section{Literature cited}

Airy Shaw 1966. Willis' Dictionary of the Flowering Plants and Ferns. Cambridge, at the univ. press.

Bowden, W. M. 1940. Diploidy, polyploidy and winter hardiness relationships in the flowering plants. Amer. Jour. Bot. 27: 357-371.

- 1945. A list of chromosome numbers in higher plants. Amer. Jour. Bot. 32: 81-92.

Darlington, C. D. and Wylie, A. P. 1955. Chromosome Atlas of Flowering Plants. George Allen and Unwin Ltd., London.

*Delay, C. 1950 . Nombres chromosomiques chez les Phanerogams. Rev. Cytol. et Biol. Veg. 12: $1-368$.

Earl, G. 1955. Chromosome numbers in the Araceae. Virginia Jour. Sci. NS. 6: 249.

Evans, O. D. 1962. Araceae. Contrib. New S. Wales Nat. Harb., Fl. Series 22: 6-13.

Hooker, J. D. 1894. The Flora of British India. Vol. VI. L. Reeve and Co., London.

Hotta, M. 1971. Study of the family Araceae. Jap. Jour. Bot. 20 (4) : 269-310. 
Hutchinson, J. 1959. The Families of Flowering Plants. II. Monocotyledons. MacMillan and Co., London.

Huttleston, D. G. 1949. The three subspecies of Arisaema triphyllum. Bull. Torrey. Bot. Cl. 76: $407-413$.

Ito, T. 1942. Chromosomen und Sexualität der Araceae I. Somatische Chromosomzahlen einiger Arten. Cytologia 12: 313-325.

Jones, G. E. 1957. Chromosome numbers and phylogenetic relationships in the Araceae. Diss. Abstr. 17: 2394.

Larsen, K. 1969. Studies in the Flora of Thailand. Cytology of vascular plants III. A study of Thai Aroids. Dansk. Botanisk Arkiv 27 (1): 39-60.

Malik, C. P. 1961. Chromosome morphology of some species of Arisaema. Phyton (B.A.). 16: 69-76.

Marchant, C. J. 1972. Chromosome variation in Araceae IV. Areae. Kew Bull. 26 (3): 395-404.

Mitra, K. and Datta, N. 1967. In IOPB chromosome number reports XIII. Taxon 16: 447.

Nakajima, G. 1933. Chromosome numbers in some angiosperms. Jap. Jour. Genet. 9:1-5.

Sharma, A. and Sarkar, A. K. (Editors) 1967-68. Chromosome number reports of plants. In Annual report, Cytogenetics Laboratory, Department of Botany, University of Calcutta. The Research Bulletin 2: 38-48.

Sharma, A. K. and Mukhopadhyay, S. 1965. Chromosome studies in Typhonium and Arisaema with a view to find out the mode of origin and the affinity of the two. Cytologia 30: $58-66$.

Simmonds, N. W. 1954. Chromosome behaviour in some tropical plants. Heredity 8: 139-146.

*Tschermak-Woess, E. 1954. Über die Phasen der Endomitose, Herkunft und Verhalten der 'Nuclealen Körper' und Beobachtungen zur karyologischen Anatomie vor Sauromatum guttatum. Planta 44: 509-531.

* Not consulted in original. 